\title{
Effectiveness of phosphorus control under extreme heatwaves: implications for sediment nutrient releases and greenhouse gas emissions
}

\author{
Qing Zhan (1) • Cleo N. Stratmann · Harm G. van der Geest • Annelies J. Veraart • \\ Kristof Brenzinger $\cdot$ Miquel Lürling $\cdot$ Lisette N. de Senerpont Domis
}

Received: 9 February 2021 / Accepted: 16 September 2021 / Published online: 2 October 2021

(C) The Author(s) 2021

\begin{abstract}
Eutrophication has been identified as the primary cause of water quality deterioration in inland waters worldwide, often associated with algal blooms or fish kills. Eutrophication can be controlled through watershed management and in-lake measures. An extreme heatwave event, through its impact on mineralization rates and internal nutrient loading (phosphorus- $\mathrm{P}$, and nitrogen- $\mathrm{N}$ ), could counteract eutrophication control measures. We investigated how the effectiveness of a nutrient abatement technique is
\end{abstract}

Responsible Editor: Amy M. Marcarelli.

Supplementary Information The online version contains supplementary material available at https://doi.org/10.1007/ s10533-021-00854-z.

Q. Zhan $(\varangle) \cdot$ C. N. Stratmann .

L. N. de Senerpont Domis

Department of Aquatic Ecology, Netherlands Institute of Ecology (NIOO-KNAW), P.O. Box 50,

6708 PB Wageningen, The Netherlands

e-mail: Q.Zhan@nioo.knaw.nl

Q. Zhan · C. N. Stratmann · M. Lürling ·

L. N. de Senerpont Domis

Department of Aquatic Ecology and Water Quality

Management, Wageningen University \& Research,

P.O. Box 47, 6708 PB Wageningen, The Netherlands

\section{N. Stratmann}

Leesu, Ecole des Ponts ParisTech, Université Paris-Est

Créteil, 6-8 avenue Blaise Pascal,

77455 Marne-la-Vallée Cedex 2, France impacted by an extreme heatwave, and to what extent biogeochemical processes are modulated by exposure to heatwaves. To this end, we carried out a sedimentincubation experiment, testing the effectiveness of lanthanum-modified bentonite (LMB) in reducing nutrients and greenhouse gas emissions from eutrophic sediments, with and without exposure to an extreme heatwave. Our results indicate that the effectiveness of LMB may be compromised upon exposure to an extreme heatwave event. This was evidenced by an increase in concentration of $0.08 \pm 0.03 \mathrm{mg} \mathrm{P} / \mathrm{L}$ with an overlying water volume of $863 \pm 21 \mathrm{~mL}$, equalling an $11 \%$ increase, with effects lasting to the end of the experiment. LMB application generally showed no effect on nitrogen

H. G. van der Geest

Department of Freshwater and Marine Ecology, Institute for Biodiversity and Ecosystem Dynamics, University of Amsterdam, P.O. Box 94240, 1090 GE Amsterdam, The Netherlands
A. J. Veraart
Department of Aquatic Ecology and Environmental Biology, Institute for Water and Wetland Research, Radboud University, P.O. Box 9010, 6500 GL Nijmegen, The Netherlands
K. Brenzinger
Department of Microbial Ecology, Netherlands Institute of Ecology (NIOO-KNAW), P.O. Box 50, 6708 PB Wageningen, The Netherlands 
species, while the heatwave stimulated nitrification, resulting in ammonium loss and accumulation of dissolved oxidized nitrogen species as well as increased dissolved nitrous oxide concentrations. In addition, carbon dioxide $\left(\mathrm{CO}_{2}\right)$-equivalent was more than doubled during the heatwave relative to the reference temperature, and LMB application had no effect on mitigating them. Our sediment incubation experiment indicates that the rates of biogeochemical processes can be significantly accelerated upon heatwave exposure, resulting in a change in fluxes of nutrient and greenhouse gas between sediment and water. The current efforts in eutrophication control will face more challenges under future climate scenarios with more frequent and intense extreme events as predicted by the IPCC.

Keywords Lake restoration - Climate change . Phoslock ${ }^{\circledR} \cdot$ Internal loading $\cdot$ GHG emission

\section{Introduction}

Eutrophication has been identified as the primary cause of water quality deterioration in inland waters worldwide across decades (Schindler 1974; Smith et al. 2006). Eutrophication is caused by the overenrichment of nutrients in surface waters, such as nitrogen (N, Howarth and Marino 2006) and phosphorus (Carpenter 2008), resulting in increased primary productivity. The nutrients that originate from external sources in the catchment and from weathering of lake sediments stimulate autochthonous organic matter production (Smith et al. 1999), which may accumulate in lake sediments. This internal nutrient storage, mostly $\mathrm{P}$ due to denitrification driven $\mathrm{N}$ losses, may periodically be recycled in the water column (Søndergaard et al. 2013). A key symptom of eutrophication is the development of algal blooms (Kalff and Knoechel 1978) that may hamper provisioning of ecosystem services such as drinking water and recreation, resulting in economic losses as well as negative impacts on quality of human life (Grizzetti

\section{K. Brenzinger}

Department of Animal Ecology and Tropical Biology, Biocenter, University of Würzburg, Am Hubland, 97074 Würzburg, Germany et al. 2016). A consequence of eutrophication-related organic matter deposition is oxygen depletion that may influence global warming potential by increasing methane emissions from lakes and impoundments (DelSontro et al. 2018; Beaulieu et al. 2019).

To counter environmental degradation, there is a need to control eutrophication and reduce nutrient loading. Apart from catchment-level nutrient abatement techniques such as wastewater treatment and control of fertilizer application, in-lake measures are becoming an effective tool for minimising algae nuisance (Lürling and Mucci 2020). In-lake restoration measures can generally be divided into two categories: symptom-oriented, i.e. not directly targeting nutrients but rather targeting the nuisance associated with water quality deterioration, and sourceoriented mitigation, i.e. directly targeting nutrients. Examples of the former are aeration/mixing that improves hypolimnetic oxic conditions and hampers surface accumulations of algae (Beutel and Horne 1999; Visser et al. 2016), coagulation of algae cells (Liu et al. 2013), fish-stock reduction that improves clarity and sediment resuspension (Hosper and Meijer 1993). Examples of source-oriented mitigation are dredging of nutrient-enriched sediments (Zhang et al. 2010) or the application of phosphorus locking agents that precipitate and immobilize phosphorus (Lurling et al. 2016). Phosphorus locking agents that reduce $P$ availability for organism growth provide a promising avenue for in-lake measures. A widely used $P$ fixative is lanthanum-modified bentonite (LMB), sold under the Phoslock ${ }^{\circledR}$ trademark (Douglas 2002), which is designed to remove dissolved reactive phosphorus from the water column and to block P release from the sediment by forming an insoluble lanthanum-phosphate complex $\left(\mathrm{LaPO}_{4}\right)$. LMB settled at the sediment can thus provide an active barrier for $\mathrm{P}$ fluxes from the sediment, promoting oligotrophication. In comparison with many other chemical locking agents, LMB can keep $\mathrm{P}$ locked under a wide range of environmental conditions, such as under high $\mathrm{pH}$, unlike iron and aluminium based products (Mucci et al. 2018); under low $\mathrm{pH}$, unlike calcium-bound $\mathrm{P}$ (Lin et al. 2015; Copetti et al. 2016); and under low redox conditions, unlike iron- and manganese-bound P) (Mucci et al. 2018). Binding/complexation with other oxyanions/ humic substance is only a kinetic hindrance of LMB (Lurling et al. 2014). A laboratory study by Zamparas et al. (2012) showed that the P-adsorption capacity by 
LMB can be enhanced with increased temperature (from 5 to $35^{\circ} \mathrm{C}$ ) due to the enlargement of pore size and/or activation of the bentonite surface.

Lake heatwaves (periods of extremely warm lake surface temperatures) are reaching higher temperatures and are lasting longer under climate change (Woolway et al. 2021), which, through subsequent impacts on mineralization rates and internal nutrient loading, could potentially counteract the current efforts in lake restoration. Heatwaves enhance thermal stability, resulting in deep-water anoxia (Jankowski et al. 2006). As a consequence, under anoxic conditions iron- and manganese-bound $\mathrm{P}$ in lake sediments can be released and become bioavailable (Beutel et al. 2008). Rising water temperatures can also increase internal loading by enhancing carbon $(C)$ mineralization rates (Gudasz et al. 2010) and liberating nutrients. Moreover, heatwaves could reinforce global warming regimes through greenhouse gas (GHG: carbon dioxide $-\mathrm{CO}_{2}$, methane $-\mathrm{CH}_{4}$, nitrous oxide $-\mathrm{N}_{2} \mathrm{O}$ ) emissions from lake sediments (Bartosiewicz et al. 2016). Although studies on combined effects of nutrients and warming show strong interactive effects on GHG emission (Davidson et al. 2015, 2018; Aben et al. 2017), little is known about specific effects of heatwaves and restoration measures. Microbial processes like mineralization, nitrification and denitrification are all temperature dependent (Veraart et al. 2011; de Klein et al. 2017), while restoration measures may modulate these processes by reducing $\mathrm{C}, \mathrm{N}$ and $\mathrm{P}$ availabilities needed for microbial activities (Redfield 1958). As a result, the nutrient cycling and GHG emission can be largely changed by the altered microbial processes due to restoration and climate change even without considering the role of primary producers.

Most experimental studies on the efficacy of eutrophication control measures under climate change to date used continuous warming temperature scenarios (Cabrerizo et al. 2020), while few have investigated sudden and large temperature boosts (i.e. heatwaves) and the potential for post-heatwave recovery in lakes. Given its rather sudden and short-term characteristics, the heatwave impacts may be transient rather than long-lived. In our study, we conducted an exposure scenario where we exposed our systems to a heatwave, with prior- and post-heatwave monitoring of water quality, enabling us to study the potential for post-heatwave recovery in lakes. We investigated if the effectiveness of the well-established nutrient abatement technique Phoslock ${ }^{\circledR}$ (hereafter LMB) is impacted by an extreme heatwave, and how this affects potential lake GHG emissions. We measured sediment nutrient release and dissolved GHG concentrations at the sediment-water interface in a threeweek sediment incubation experiment. We used unmodified bentonite as a control treatment to account for the potential effects of bentonite clay in the LMB treatment.

We tested three hypotheses: (1) Heatwaves will enhance sediment nutrient releases by increasing mineralization rates and decreasing oxygen concentrations; (2) LMB can reduce the potential heatwaveinduced P-release by reducing P-availability in the sediments; and (3) GHG emissions in LMB treated systems will be mitigated due to a reduction in nutrient availabilities.

\section{Materials and methods}

Experimental design

\section{Pre-treatment}

On 21 June 2018, sediments were collected in 39 cores (60 $\mathrm{cm}$ in length and $6 \mathrm{~cm}$ in diameter) with overlying water column at a depth of $1.85 \mathrm{~m}$ from a eutrophic Dutch pond $\left(52^{\circ} 02^{\prime} 20.6 “ \mathrm{~N} 5^{\circ} 38^{\prime} 51.4\right.$ ” E) using a UWITEC gravity core sampler. Pond water was sampled from three depths of the water column $(0 \mathrm{~m}, 0.5 \mathrm{~m}, 1.5 \mathrm{~m})$. Three of the 39 sediment cores were selected for analyses of $\mathrm{P}$ pools in the sediments, whereas the remaining 36 cores were designated for the experiment.

On these 3 cores, we carried out a $\mathrm{P}$ fractionation method following Cavalcante et al. (2018) for the top $10 \mathrm{~cm}$ sediment to determine loosely bound $\mathrm{P}\left(\mathrm{H}_{2} \mathrm{O}\right.$ $\mathrm{P}$ ), redox-sensitive $\mathrm{P}$ (BD-P), metal oxide-bound $\mathrm{P}$ (NaOH-P), Calcium-bound $\mathrm{P}(\mathrm{HCl}-\mathrm{P})$ and residual $\mathrm{P}$ (residual-P). Each fraction of $\mathrm{P}$ consists of soluble reactive $P$ (SRP) and non-reactive $P(N R P)$ that represents the organic part. The sediment pools of mobile $\mathrm{P}$, which can be released in anoxic conditions or by organic matter degradation and become bioavailable, was determined by the sum of the SRPs of the $\mathrm{H}_{2} \mathrm{O}-\mathrm{P}$ and BD-P fractions and the NRP of the NaOH$P$ fraction (Cavalcante et al. 2018). The sum of other $P$ 
forms represents the non-mobile sediment $\mathrm{P}$ pool, i.e. the difference between the sum of all $\mathrm{P}$ forms and the above-mentioned mobile $\mathrm{P}$ forms. In our treatments, we determined LMB doses based on the mobile sediment $\mathrm{P}$ pool.

Upon transportation into the laboratory, the undisturbed sediment cores were placed in a temperaturecontrolled water bath at $20{ }^{\circ} \mathrm{C}$. $20{ }^{\circ} \mathrm{C}$ is regarded as a baseline temperature for the experiment, similar to the pond water temperature during core collection. Water temperature was continuously recorded during the course of the experiment. The cores were open to the air throughout the experiment and were kept dark most of the time to prevent algal growth. The cores were exposed to light during the sampling events of around one hour, when the light ranged between 0.01 and $104.0 \mu \mathrm{mol}$ photons $\mathrm{m}^{-2} \mathrm{~s}^{-1}$. Sediments were acclimatized to the laboratory conditions for 5 days prior to the experiment.

\section{Treatment}

LMB was obtained from Phoslock ${ }^{\circledR}$ Europe $\mathrm{GmbH}$ (Manchester, UK). To test the effectiveness of LMB under a heatwave scenario, we split the 36 sediment cores into three groups such that 12 cores were treated with LMB, 12 cores were treated with bentonite (Bent) and the other 12 cores were left untreated (Ctrl) (Fig. 1). We made a slurry of $380 \mathrm{mg} \mathrm{LMB}$ resuspended in water from each LMB treatment unit and added the slurry at the top of the core, targeting the amount of potential releasable $P$ in the top $3.3 \mathrm{~cm}$ of the sediment to achieve an LMB:P ratio of 100:1 (see Table 1 for details on calculation of LMB dose). The same dose of bentonite was added to the 'Bent' treatment to control for potential physical capping of sediment in the LMB treatment.

All of the 36 sediment cores were kept at $20{ }^{\circ} \mathrm{C}$ during the first week (Fig. S1). During the second week, a heatwave scenario was simulated by exposing half of the cores of all $\mathrm{P}$ control treatments (i.e. LMB, Bent and Ctrl, 18 cores in total) to a temperature of $30{ }^{\circ} \mathrm{C}$, whilst half of the cores of all $\mathrm{P}$ control treatments (LMB, Bent and Ctrl) were kept at $20^{\circ} \mathrm{C}$, yielding 6 replicates in each treatment unit (Fig. 1). After one week at $30{ }^{\circ} \mathrm{C}$, the heatwave cores were all returned to the baseline temperature of $20^{\circ} \mathrm{C}$. The heatwave scenario is similar to the recent summer conditions (2015-2020) in the Netherlands where the

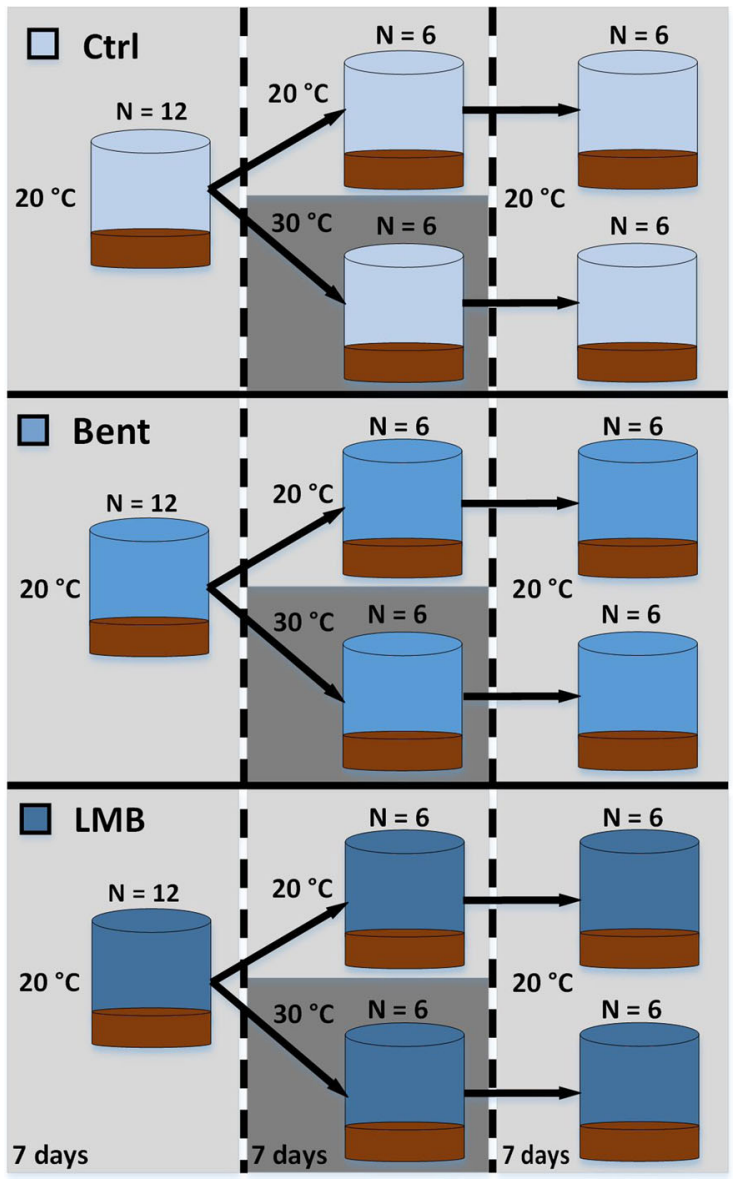

Fig. 1 Experimental design. 'Ctrl' represents control without adding P-binding materials; 'Bent' represents bentonite treatment; 'LMB' represents Phoslock ${ }^{\circledR}$ treatment. Shaded boxes represent sediment cores exposed to heatwaves

average temperature during heatwave that lasted weeks was around $30 \mathrm{oC}$ (KNMI data, https://data. knmi.nl/). In the experimental heatwave scenarios, the heating and cooling of the water columns were realized within one day to simulate a sudden temperature boost scenario. As a result, we were able to monitor the dynamics of different water quality parameters before, during and after the heatwave in different treatment units.

Water and sediment measurements

We sampled a suite of water quality variables including dissolved oxygen concentrations $\left(\mathrm{O}_{2}\right), \mathrm{pH}$, conductivity, dissolved inorganic nutrients and dissolved GHG at $10 \mathrm{~cm}$ above the sediment surface of 
Table 1 Calculation of Phoslock ${ }^{\circledR}$ (LMB) dose

\begin{tabular}{|c|c|c|c|}
\hline Step & Calculation & Unit & Value \\
\hline Target sediment depth & & $\mathrm{cm}$ & 3.3 \\
\hline Target sediment volume & Target sediment depth $\times$ core area & $\mathrm{cm}^{3}$ & 93.31 \\
\hline Potentially available $\mathrm{P}$ of the sediment & Sum of mobile $\mathrm{P}$ forms $\times$ target sediment volume & $\mathrm{mgP}$ & 3.8 \\
\hline La:P weight ratio & molar mass of $\mathrm{La}(=138.9) \div$ molar mass of $\mathrm{P}(=31)$ & - & 4.48:1 \\
\hline Amount of La needed for target volume & Available $\mathrm{P} \times \mathrm{La}: \mathrm{P}$ weight ratio & $\mathrm{mg}$ & 17.024 \\
\hline Phoslock ${ }^{\circledR}(\mathrm{LMB})$ applied & $\begin{array}{l}\text { Amount of La needed for target volume } \div \text { La content } \\
(=4.5 \%, \text { Lurling et al. } 2014)\end{array}$ & $\mathrm{mg}$ & 380 \\
\hline
\end{tabular}

each of the experimental units. We sampled SRP, $\mathrm{NO}_{3}-\mathrm{N}+\mathrm{NO}_{2}-\mathrm{N}$ and $\mathrm{NH}_{4}-\mathrm{N}$, and carbon dioxide $\left(\mathrm{CO}_{2}\right)$, methane $\left(\mathrm{CH}_{4}\right)$ and nitrous oxide $\left(\mathrm{N}_{2} \mathrm{O}\right)$ in total eight times along the course of the experiment (2-3 times/week). Metals, i.e. lanthanum (La), calcium $(\mathrm{Ca})$, iron $(\mathrm{Fe})$, aluminium $(\mathrm{Al})$ and manganese $(\mathrm{Mn})$ were sampled three times during the experiment (1 time/week). We used handheld sensors to instantaneously measure $\mathrm{O}_{2}$ (HQ40d Portable probe, Hach, Colorado, US), $\mathrm{pH}$ and conductivity (WTW Multi 350i, Geotech Environmental Equipment Inc., Colorado, US). After filtration of water samples over prewashed GF/F filters (Whatman, Maidstone, U.K.) we analysed the filtrate for SRP, $\mathrm{NO}_{3}-\mathrm{N}+\mathrm{NO}_{2}-\mathrm{N}$ and $\mathrm{NH}_{4}-\mathrm{N}$, using an QuAAtro39 Auto-Analyzer (SEAL Analytical Ltd., Southampton, U.K.). In addition, we measured concentrations of $\mathrm{La}, \mathrm{Ca}, \mathrm{Fe}, \mathrm{Al}$ and $\mathrm{Mn}$ in the filtrate by inductively coupled plasma optical emission spectrometry (iCAP6500 Duo, ThermoFisher, U.K.).

The concentrations of GHGs in the water column were determined by a headspace equilibration technique described in Magen et al. (2014) and Halbedel (2015). Briefly, water samples were introduced in a syringe, where air was introduced and the dissolved GHGs were equilibrated with the headspace by shaking the syringe vigorously for two minutes. Afterwards, the equilibrated headspace gas was collected and analysed for GHG concentrations in a Gas Chromatography (TRACE $^{\mathrm{TM}} 1300$ GC, ThermoFisher, U.K.) machine equipped with a Flame Ionization Detector (FID) and an Electron Capture Detector (ECD). Calculations for the water column concentrations were based on Halbedel (2015), in which we used parameters from Weiss (1974) for $\mathrm{CO}_{2}$, Yamamoto et al. (1976) for $\mathrm{CH}_{4}$, and Weiss and Price
(1980) for $\mathrm{N}_{2} \mathrm{O}$. Note that the $\mathrm{CO}_{2}$ concentrations in our system were far beyond atmospheric $\mathrm{CO}_{2}$ equilibrium $(\approx 412 \mathrm{ppm})$, therefore the limits of the headspace method to analyse the partial $\mathrm{CO}_{2}$ concentration in water discussed in Koschorreck et al. (2021) is not relevant in our case.

To gain a close understanding of the anoxic conditions in the sediments in addition to the $\mathrm{O}_{2}$ concentrations measured in the overlying waters, 12 cores ( 2 cores randomly chosen from each of the six treatment groups) were equipped with redox probes. Redox potential dynamics were continuously recorded (time interval of $10 \mathrm{~min}$ ) at 12 different depths above and/or below the sediment water interface $(\max =14$ $\mathrm{cm}$ depth below the sediment surface).

After the experiment was completed, the P-fractions in 24 out of 36 cores (the ones without a redox probe, i.e. 4 cores from each treatment) were determined using the same method described for the three initial cores above. Besides the mobile $\mathrm{P}$, their nonmobile P (i.e. the sum of the NRPs of the $\mathrm{H}_{2} \mathrm{O}-\mathrm{P}$, BD-P fractions, the SRP from NaOH-P fraction and $\mathrm{HCl}-\mathrm{P}$ and residual-P fractions) was also determined.

\section{Statistical analysis}

The effects of the experimental treatments on the dynamics of different variables including $\mathrm{O}_{2}, \mathrm{pH}$, SRP, $\mathrm{NH}_{4}-\mathrm{N}, \mathrm{NO}_{3}-\mathrm{N}+\mathrm{NO}_{2}-\mathrm{N}, \mathrm{CO}_{2}, \mathrm{CH}_{4}$, and $\mathrm{N}_{2} \mathrm{O}$ were analysed by a linear mixed-effect model (LME; Lindstrom and Bates, 1988), with each of the variables as the univariate response variable. The $\mathrm{P}$ treatments (Ctrl, Bent, or LMB) and temperatures were included as fixed effects. Day in the experiment was taken as an additional fixed effect to evaluate the changes in response variables through time. Differences among 
subjects (cores) were taken as a random effect in the LME model. The LME model corresponds to:

$$
\begin{aligned}
y_{i k}= & \beta_{0}+\sum_{m=2}^{3} \beta_{1 m k} \times I[P]_{i m k}+\beta_{2 k} \times \text { Temp }_{i k}+\beta_{3 k} \\
& \times \text { Time }_{i k}+b_{0 k}+\varepsilon_{i k}
\end{aligned}
$$

where $i=1,2, \ldots, 288$, index $k=1,2, \ldots, 36$ corresponds to the 36 cores, $\mathrm{m}=2,3$ corresponds to the $\mathrm{P}$ control measures. $\beta$ are the fixed-effects coefficients. $I[P]_{i m}$ is the dummy variable representing the level $\mathrm{m}$ of the $\mathrm{P}$ treatments. Temp ${ }_{i k}$ stands for temperature, and Time $_{i k}$ stands for time. $b_{0 k}$ is the random effect for level $\mathrm{k}$ of cores, and $\varepsilon_{i k}$ is the observation error for observation $i$. The random effect has the prior distribution,

$b_{0 k} \sim N\left(0, \sigma_{b}^{2}\right)$,

And the error term has the distribution,

$\varepsilon_{i k} \sim N\left(0, \sigma^{2}\right)$.

We analysed three phases in the experiment separately. First, we analysed the period before the heatwave (days 1-7), where we only evaluated the effects of the $\mathrm{P}$ treatments and time. Second, we analysed the period during the heatwave (days 8-14), where we evaluated the effect of the different temperature treatments (heatwave vs non-heatwave exposed treatments) in addition to the effects of $P$ treatments and time. Finally, we analysed the post heatwave period (days 15-21), where we evaluated the effects of $\mathrm{P}$ treatments and the recovery from the heatwave over time. The normality and heteroscedasticity of the residuals were tested by Shapiro Wilk test (Ghasemi and Zahediasl 2012) and Breusch Pagan test (Waldman 1983), respectively. For the data that did not pass the test for normality, we applied a data transformation method (i.e. square root transformation for $\mathrm{O}_{2}, \mathrm{pH}, \mathrm{NO}_{2}$ and $\mathrm{NO}_{3}$, and logarithm transformation for $\mathrm{CH}_{4}$ ). To account for heteroscedasticity, we deployed a weighted linear mixed-effect model (Zuur et al. 2009).

Determination of differences between the sediment $P$ forms after the experiment were performed through two-way analysis of variance (ANOVA) with heatwave and $\mathrm{LMB} / \mathrm{Bent}$ treatments as factors. In addition, we carried out two-way ANOVA analyses to determine the differences between metal concentrations in the heatwave phase as well as in the post-heatwave phase. All statistical analyses in this study were performed in $\mathrm{R}$ language ( $\mathrm{R}$ Core Team 2019). We used the packages lubridate (Grolemond and Wickman 2011), ggplot2 (Villanueva and Chen 2019), nlme (Pinheiro et al. 2019) and vegan (Oksanen et al. 2019).

\section{Results}

Pre-treatment conditions

At the moment of field-sampling, water transparency measured with a Secchi disc was $0.54 \mathrm{~m}, \mathrm{pH}$ was $7.52 \pm 0.0$, temperature was $19.5 \pm 0.0{ }^{\circ} \mathrm{C}$ and $\mathrm{O}_{2}$ concentration was $3.8 \pm 0.1 \mathrm{mg} / \mathrm{L}$ and no apparent water stratification was observed. The soluble reactive phosphorus (SRP) concentration was $0.14 \pm 0.02 \mathrm{mg}$ $\mathrm{P} / \mathrm{L}$, the ammonium $\left(\mathrm{NH}_{4}-\mathrm{N}\right)$ concentration was $0.56 \pm 0.13 \mathrm{mg} \mathrm{N} / \mathrm{L}$, and the sum of nitrate and nitrite $\left(\mathrm{NO}_{3}-\mathrm{N}+\mathrm{NO}_{2}-\mathrm{N}\right)$ was $0.04 \pm 0.08 \mathrm{mg} \mathrm{N} / \mathrm{L}$. The total dissolved carbon (TDC) averaged $49.1 \pm 3.1 \mathrm{mg} / \mathrm{L}$, with an inorganic dissolved carbon (IDC) concentration of $36.9 \pm 0.4 \mathrm{mg} / \mathrm{L}$ and a dissolved organic carbon (DOC) concentration of $12.2 \pm 3.0 \mathrm{mg} / \mathrm{L}$.

The sediment layers in the cores were at least $15 \mathrm{~cm}$ deep. The sediment was very fluffy with an average water content of $90.7 \pm 1.5 \%$, a dry weight (DW) density of $0.10 \pm 0.02 \mathrm{~g} / \mathrm{mL}$, and an average organic matter (OM) amount of $0.022 \pm 0.001 \mathrm{~g} / \mathrm{mL}$ wet sediment.

Nutrients and metals dynamics and responses

In all treatments the initial SRP concentration in the water columns started at a similar level of $0.71 \mathrm{mg} \mathrm{P} / \mathrm{L}$ $(\mathrm{SE}= \pm 0.06)$ and changed significantly throughout the experimental periods (Fig. 2a). After LMB application the amount of SRP in the water column of our experimental units dropped by $83 \%$ within two days, whereas in the non-LMB groups (i.e., Ctrl and Bent treatments) a continuous increase in the SRP concentrations was observed along the entire course of experiment, up to $1.24 \pm 0.10 \mathrm{mg}$ P/L. No significant difference between Ctrl and Bent treatments were detected, with SRP concentrations increasing at a similar rate over time in both groups regardless of heatwave treatment (effect of increasing rate $=0.027$ 


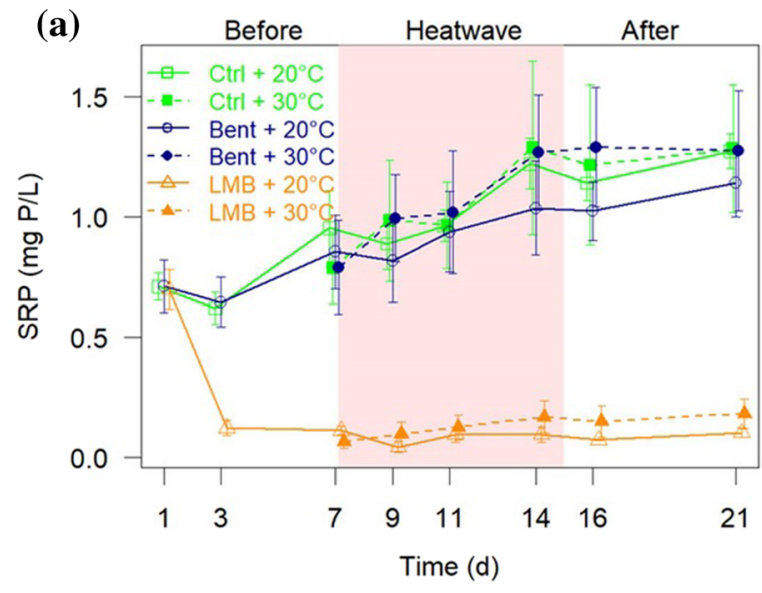

Fig. 2 a Dynamics of soluble reactive phosphorus (SRP) in the water column. Error bars indicate the standard error. The pink shading indicates exposure to different temperature regimes $\left(20{ }^{\circ} \mathrm{C}\right.$ in solid lines and $30{ }^{\circ} \mathrm{C}$ in dashed lines); before and after the pink shading shows all P-treatments (Ctrl, Bent and LMB) at

mg P/L/day, $\left.\mathrm{F}_{1,162}=117.5, p<0.001\right)$. In contrast, in LMB-exposed groups, upon exposure to the heatwave, SRP concentrations were significantly increased compared to the non-heatwave exposed treatments (estimate of difference $=49 \%$, $\mathrm{F}_{1,58}=14.20, p<0.001$ ), with effects lasting to the end of the experiment. The heatwave-induced elevation of SRP concentrations in LMB exposed treatments ranged between 0.05 and $0.08 \mathrm{mg} \mathrm{P} / \mathrm{L}$.

After completion of the experiment, the sediment $\mathrm{P}$ fractionation analyses showed different $\mathrm{P}$ pools among different P-binding treatments, with Ctrl treatments of $430.3 \pm 81.6 \mu \mathrm{g} \mathrm{P} / \mathrm{g}$ DW, Bent treatments of $494.6 \pm 198.1 \mu \mathrm{g} \mathrm{P} / \mathrm{g}$ g DW and LMB treatments of $590.9 \pm 177.9 \mu \mathrm{g} \mathrm{P} / \mathrm{g}$ DW (Fig. 2b). According to the two-way ANOVA test of different $\mathrm{P}$ pools, heatwave exposure resulted in a significantly lower redox sensitive $\mathrm{P}$ pool (BD-P) than the non-heatwave treatments (estimate of difference $=7 \%$, $\left.\mathrm{F}_{1,113}=12.2, p<0.001\right)$. Such heatwave-induced decrease in BD-P was not observed in the LMB addition groups. Other sediment $\mathrm{P}$ forms showed no significant heatwave effects, but LMB addition led to significantly higher contents of metal oxide-bound $\mathrm{P}$ $\left(\mathrm{NaOH}-\mathrm{P}\right.$, estimate of difference $=86 \%, \mathrm{~F}_{2,114}=7.9$, $p<0.001)$ and calcium-bound $\mathrm{P}$ (HCl-TP, estimate of difference $\left.=42 \%, \mathrm{~F}_{2,114}=7.9, p<0.001\right)$.

We analysed $\mathrm{NH}_{4}-\mathrm{N}$ and $\mathrm{NO}_{3}-\mathrm{N}+\mathrm{NO}_{2}-\mathrm{N}$ as indicators of $\mathrm{N}$ dynamics in the water columns (b)

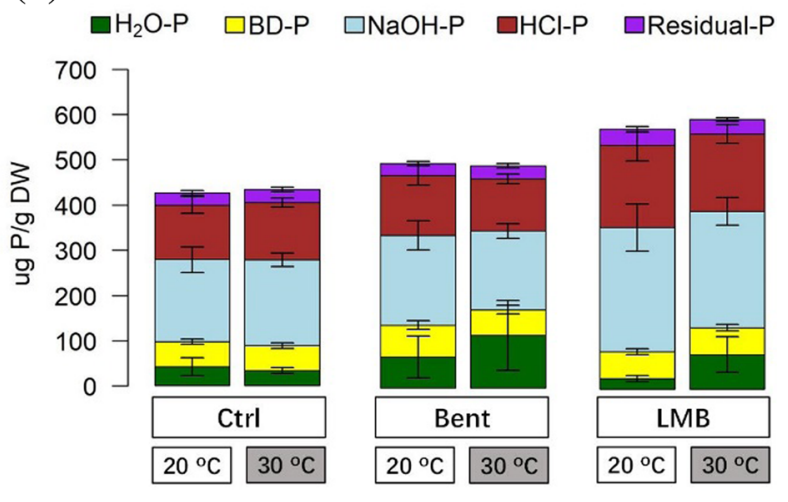

$20^{\circ} \mathrm{C}$. b Phosphorus (P) fractions in sediments ( $\mu \mathrm{g} \mathrm{P} / \mathrm{g} \mathrm{DW}$ ). The labels on the $\mathrm{x}$-axis illustrate treatment units: 'Ctrl' for no $\mathrm{P}$ treatments (i.e., no LMB/bentonite), 'Bent' for bentonite and 'LMB' for Phoslock ${ }^{\circledR}$; ' $20{ }^{\circ} \mathrm{C}$ ' for non-heatwave exposed groups and $30{ }^{\circ} \mathrm{C}$ for heatwave exposed groups

(Fig. 3). In all treatments $\mathrm{NH}_{4}-\mathrm{N}$ had a slight increase in the first week from $3.54 \pm 0.25$ to $4.58 \pm 0.29 \mathrm{mg} \mathrm{N} / \mathrm{L}$, and then decreased to approximately $0.55 \pm 0.34 \mathrm{mg} \mathrm{N} / \mathrm{L}$ by the end of the experiment. The $\mathrm{NH}_{4}-\mathrm{N}$ concentrations for cores subjected to the heatwave were lower (estimate of difference $\left.=27 \%, \mathrm{~F}_{1}, 249=117.5, p<0.001\right)$ than those not subjected to a heatwave. The $\mathrm{NO}_{3}$ $\mathrm{N}+\mathrm{NO}_{2}-\mathrm{N}$ concentrations started to increase from the second week. The $\mathrm{NO}_{3}-\mathrm{N}+\mathrm{NO}_{2}-\mathrm{N}$ concentrations for treatments subjected to the heatwave were higher compared to the non-heatwave groups in the second week, with a decline after the heatwave leading to a lower concentration relative to the non-heatwave groups at the end of the experiment (estimate of difference $\left.=8 \%, \mathrm{~F}_{1}, 1_{174}=18.88, p<0.001\right)$. No effects of LMB/Bent additions on $\mathrm{NH}_{4}-\mathrm{N}$ or $\mathrm{NO}_{3}$ $\mathrm{N}+\mathrm{NO}_{2}-\mathrm{N}$ were detected.

Dissolved La concentrations in the LMB-exposed groups were much higher in the pre-heatwave and during the heatwave phases (estimate of difference $=91 \%, \mathrm{~F}_{2,33}=35.1, p<0.001$ ), and decreased through time, with an end concentration of $1.50 \pm 0.30 \mu \mathrm{g} \mathrm{La} / \mathrm{L}$, which is below the Dutch La standard for surface water $(=10.1 \mu \mathrm{g} \mathrm{La} / \mathrm{L})$. A decreasing trend of $\mathrm{La}$ was also observed in the treatments without LMB additions (Fig. S2a), without significant differences between LMB/Bent/Ctrl treatments in the post-heatwave phase. Dissolved Fe 


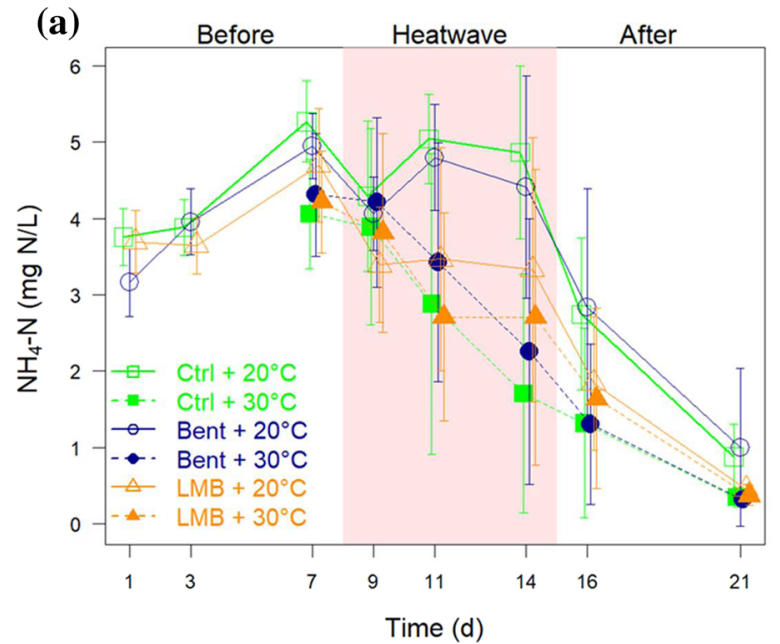

Fig. 3 Dynamics of a ammonium $\left(\mathrm{NH}_{4}-\mathrm{N}\right)$ concentration, b dissolved oxidized nitrogen (DON $\left.=\mathrm{NO}_{3}-\mathrm{N}+\mathrm{NO}_{2}-\mathrm{N}\right)$ concentration in the water column. Error bars indicate the standard error. The pink box indicates exposure to different

concentrations decreased through time (Fig. S2b), with heatwave exposure leading to higher Fe concentrations during and after heatwave phases (estimate of difference $=103 \%, \mathrm{~F}_{1,68}=9.9, p=0.003$ ), whereas no effects from $\mathrm{LMB} /$ Bent treatments were detected. Of other metals including $\mathrm{Ca}, \mathrm{Al}, \mathrm{Mn}$ and $\mathrm{S}$ we detected no effects from heatwave or LMB/Bent treatments (Fig. S2c). Both $\mathrm{Ca}$ and S concentrations decreased over time with a high correlation between them (Pearson correlation coefficient $=0.84, \mathrm{t}=19.3$, df $=105, p<0.001$, Fig. S3).

\section{Oxygen dynamics}

In all treatments the oxygen concentrations significantly increased from $0.42 \pm 0.16$ to $3.01 \pm 0.43 \mathrm{mg} / \mathrm{L}$ with time (Fig. 4, F1, $239=98.6$, $p<0.001$ ), with no effects from LMB/Bent additions detected. This was reflected by the redox dynamics (Fig. S4) which indicated reducing conditions in the water column of the cores in the starting phase, with the systems becoming more redox potential-positive towards the end of our experiment, irrespective of the treatments. In contrast to observations in the water column, redox potentials in the sediments were descending along the experiment period.

Our linear mixed effect model (LME), however, revealed a temporal reduction of oxygen concentrations during the heatwave in the heatwave treatments

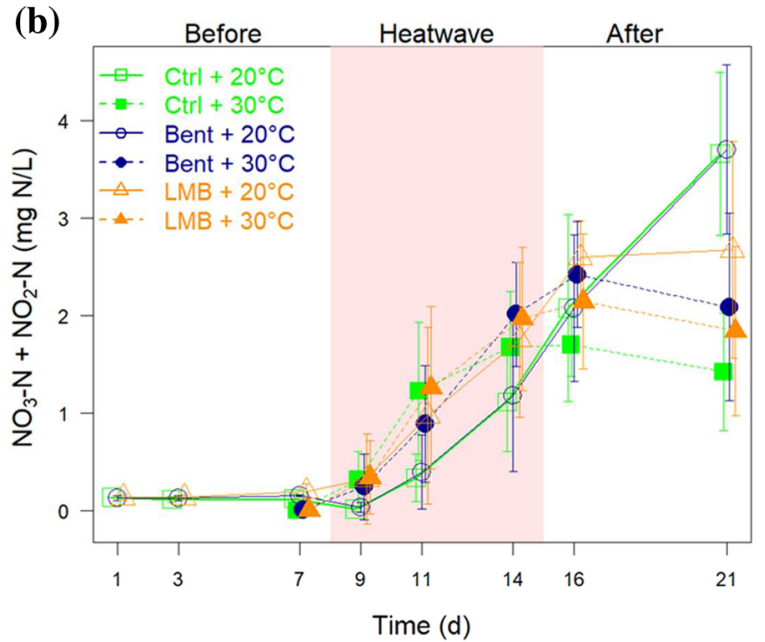

temperature regimes $\left(20^{\circ} \mathrm{C}\right.$ in solid lines and $30^{\circ} \mathrm{C}$ in dashed lines); before and after the pink box indicates all P-treatments (Ctrl, Bent and LMB) at $20^{\circ} \mathrm{C}$

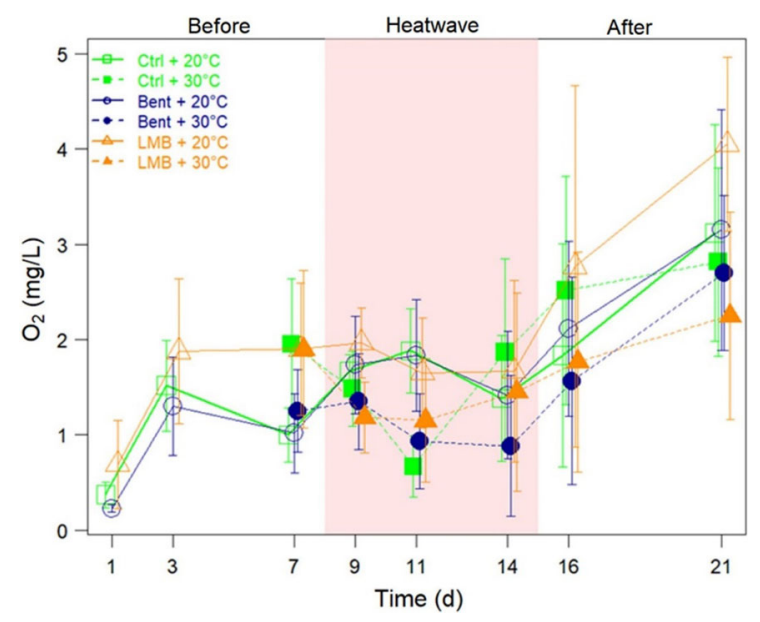

Fig. 4 Dynamics of dissolved oxygen concentration $\left(\mathrm{O}_{2}\right)$ in the water column. Error bars indicate the standard error. The pink shading indicates exposure to different temperature regimes $\left(20{ }^{\circ} \mathrm{C}\right.$ in solid lines and $30{ }^{\circ} \mathrm{C}$ in dash lines); before and after the pink shading indicates all $\mathrm{P}$-treatments (Ctrl, Bent and LMB) at $20{ }^{\circ} \mathrm{C}$

(estimate of difference $=16 \%, \mathrm{~F}_{1,34}=4.9, p=0.03$ ), with a maximum deviation by $0.87 \mathrm{mg} / \mathrm{L}$ at day 11 . This heatwave effect disappeared after the heatwave. By the end of our experiment, the oxygen concentrations were still unsaturated (saturation concentration at $20{ }^{\circ} \mathrm{C}=9.03 \mathrm{mg} / \mathrm{L}$ ). 
Dissolved greenhouse gases

We measured concentrations of dissolved greenhouse gases $\mathrm{CO}_{2}, \mathrm{CH}_{4}$ and $\mathrm{N}_{2} \mathrm{O}$, as a proxy of their emission potential. Among the three gases, $\mathrm{CO}_{2}$ concentrations were the highest, followed by $\mathrm{CH}_{4}$ and $\mathrm{N}_{2} \mathrm{O}$, with respectively a factor 10 and 100 lower levels. All three gas concentrations in the water column of the cores changed significantly over time, with significant increase during the heatwave phase (Fig. 5a for $\mathrm{CO}_{2}$, estimate of difference $=15 \%, \quad \mathrm{~F}_{1}, \quad 243=27.9$, $p<0.001$; Fig. $5 \mathrm{~b}$ for $\mathrm{CH}_{4}$, estimate of difference $=21 \%, \mathrm{~F}_{1}, 243=20.4, p<0.001$; Fig. $5 \mathrm{c}$ for $\mathrm{N}_{2} \mathrm{O}$, estimate of difference $=536 \%, \mathrm{~F}_{1,243}=116.6$,
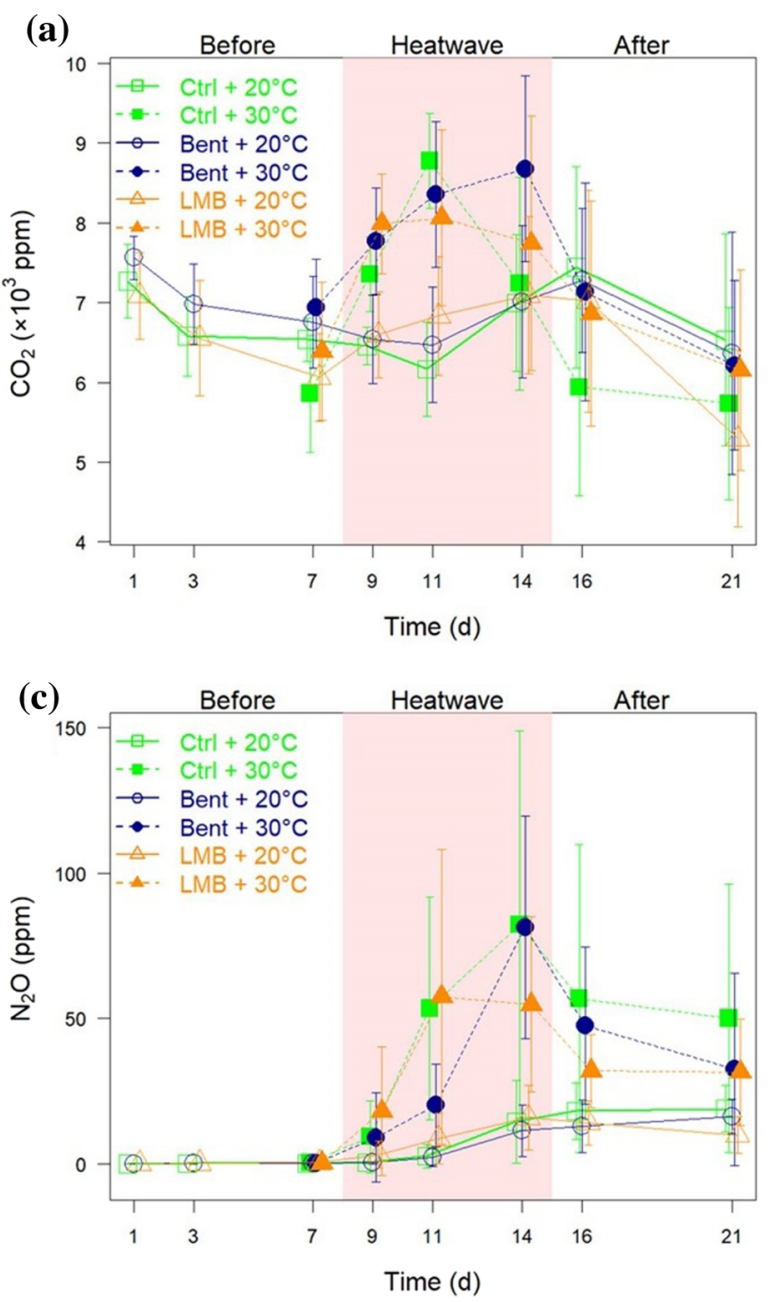

Fig. 5 Dynamics of a dissolved carbon dioxide $\left(\mathrm{CO}_{2}\right)$, b dissolved methane $\left(\mathrm{CH}_{4}\right)$ and c dissolved nitrous oxide $\left(\mathrm{N}_{2} \mathrm{O}\right)$. Error bars indicate the standard error. The pink shading indicates exposure to different temperature regimes $\left(20^{\circ} \mathrm{C}\right.$ in $p<0.001$ ), equalling an increased $\mathrm{CO}_{2}$-equivalent by $106 \%$. No effects from LMB or Bent treatments on the greenhouse gas dynamics were detected.

$\mathrm{CO}_{2}$ concentrations decreased from $7.3 \pm 0.3 \times 10^{3}$ to $6.4 \pm 0.3 \times 10^{3} \mathrm{ppm}$ in the before-heatwave phase, whereas during the heatwave phase in the heatwave-exposed treatments the $\mathrm{CO}_{2}$ concentrations rose up to $8.4 \pm 0.5 \times 10^{3} \mathrm{ppm}$. In the post-heatwave phase, $\mathrm{CO}_{2}$ concentrations in the heatwave groups dropped to the same levels as the non-heatwave treatments, resulting in an average of $6.0 \pm 0.5 \times 10^{3} \mathrm{ppm}$ by the end of the experiment.

$\mathrm{CH}_{4} \quad$ concentrations dropped from $391.98 \pm 123.98 \mathrm{ppm}$ to $62.70 \pm 45.74 \mathrm{ppm}$ in the

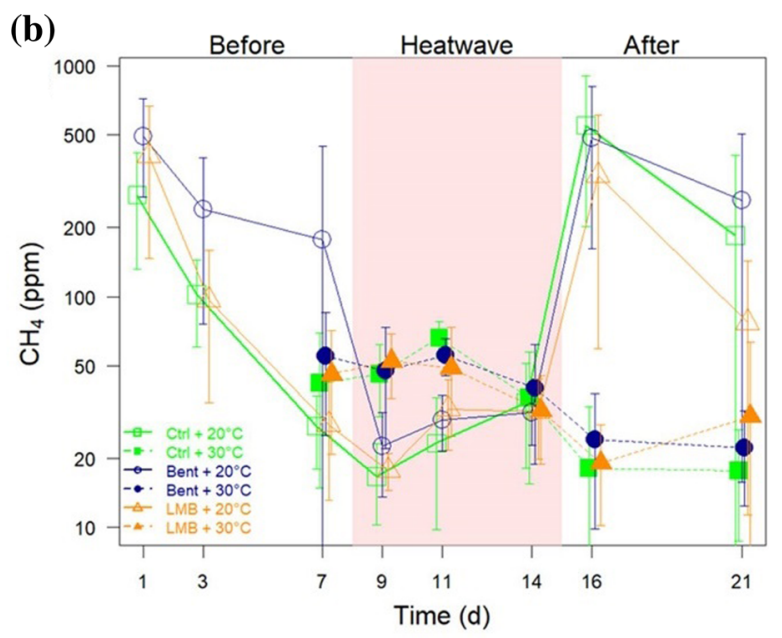

solid lines and $30{ }^{\circ} \mathrm{C}$ in dashed lines); before and after the pink shading indicates all P-treatments (Ctrl, Bent and LMB) at $20{ }^{\circ} \mathrm{C}$ 
pre-heatwave phase. During the heatwave phase, the heatwave-exposed cores were observed with higher $\mathrm{CH}_{4}$ concentrations (mean $=47.38 \pm 3.21 \mathrm{ppm}$ ) than the non-heatwave treatments $($ mean $=26.69 \pm 1.87$ ppm). However, in the post-heatwave phase (days $15-$ 21), the $\mathrm{CH}_{4}$ concentrations in the non-heatwave treatments surpassed that in the heatwave-exposed groups and reached a high average level of the same magnitude as that measured in the beginning of the experiment $($ mean $=174.25 \pm 57.39 \mathrm{ppm})$, whereas the $\mathrm{CH}_{4}$ concentrations in the heatwave-exposed cores had a relatively low-end concentration (mean $=23.40 \pm 5.84 \mathrm{ppm})$.

$\mathrm{N}_{2} \mathrm{O}$ concentrations stayed at a rather low level (mean $=0.15 \pm 0.02 \mathrm{ppm}$ ) in the before-heatwave phase. During the heatwave phase, $\mathrm{N}_{2} \mathrm{O}$ emissions started to increase in all treatments, with $\mathrm{N}_{2} \mathrm{O}$ concentrations in heatwave-exposed cores increasing at a much higher rate than in non-heatwave groups. In the period after the heatwave (days 15-21) the nonheatwave groups showed a relatively stable $\mathrm{N}_{2} \mathrm{O}$ concentration $($ mean $=15.16 \pm 2.52 \mathrm{ppm})$ until the end of the experiment. $\mathrm{N}_{2} \mathrm{O}$ concentrations in the heatwave groups increased to $72.84 \pm 26.53 \mathrm{ppm}$ during the heatwave, but in the post-heatwave phase, the concentrations dropped to $38.10 \pm 19.14 \mathrm{ppm}$, which is, however, a still higher level than the observed $\mathrm{N}_{2} \mathrm{O}$ emission in the non-heatwave groups.

\section{Discussion}

Using a full-factorial design, we investigated the combined effects of phosphorus control by lanthanummodified bentonite (LMB) and exposure to an extreme heatwave event on the biogeochemistry at the sediment-water interface and the resulting fluxes between sediment and water. For shallow waters, one of the most abundant water types (Verpoorter et al. 2014), such fluxes between water and sediment play an important role in the phosphorus, nitrogen and carbon cycling. Despite the observation that LMB was able to reduce phosphorus levels in the water column up to $91 \%$ in comparison to the control groups by the end of our experiment, LMB effectiveness was hampered upon exposure to a heatwave, resulting in increasing $\mathrm{P}$ concentrations with $11 \%$, persisting until the end of the experiment. There was no significant effect of LMB addition on nitrogen dynamics. Under low oxygen conditions $\left(\mathrm{O}_{2}<4.8 \mathrm{mg} / \mathrm{L}\right.$ in all treatments), nitrification was stimulated by increased oxygen and temperature, resulting in an accumulation of nitrate + nitrite and nitrous oxide. In addition, our results suggest that GHG dynamics were impacted upon heatwave exposure, but LMB did not affect this pattern.

The impact of heatwaves on phosphorus and nitrogen dynamics: eutrophic vs oligotrophic sediments

The continuous P-release in controls, leading to concentrations as high as $1.2 \mathrm{mg} \mathrm{P} / \mathrm{L}$ towards the end of our experiment, could be explained by the large pool of bioavailable phosphorus in sediment (Fig. 2b). This pool of bioavailable phosphorus consists of phosphorus in the pore water, redox-sensitive P (BD$\mathrm{P}$ ), and organic $\mathrm{P}$ which can be mobilized under anoxic conditions (Cavalcante et al. 2018). LMB strongly reduced phosphorus concentrations in the water column and kept those persistently low until the end of our experiment, which indicates that LMB both stripped the water column $\mathrm{P}$ and hampered sediment $\mathrm{P}$ release, as was expected from its well-documented performance (Copetti et al. 2016). The bentonite-only treatment did not have any impact on $\mathrm{P}$ dynamics relative to our controls, which further underpins that the LMB effect was a result of the $\mathrm{P}$ inactivation and not caused by depositing a thin clay layer on top of the sediment. Some studies reported a $\mathrm{P}$ abatement capacity of unmodified bentonite (Zamparas et al. 2012), but the bentonite used in our study had no P-binding capacity (Mucci et al. 2018) and the layer was evidently too thin to act as a passive barrier (Kim et al. 2007).

When we exposed the LMB-treated sediments to a one-week heatwave, phosphorus concentrations increased by $0.08 \pm 0.03 \mathrm{mg} \mathrm{P} / \mathrm{L}$ (the overlying water volume $=863 \pm 21 \mathrm{~mL}$ ) in the water column at the end of our three-week experiment (Fig. 2a), equalling an $11 \%$ increase compared to the non-heatwave exposed group. In an earlier study, however, higher P-adsorption capacity by LMB was observed under increased temperature due to the enlargement of pore size and/or activation of the bentonite surface (Zamparas et al. 2012). It is noteworthy that Zamparas et al. (2012) used a rather simple environment (3 h of experimental time, heavy mixing of the slurry with 
solution), whereas the static sediment in our experiment is a much more complex matrix with biogeochemical processes playing an important role in determining the LMB capacity. Earlier model simulations indicate that concentrations of $0.05 \mathrm{mg} \mathrm{P} / \mathrm{L}$, similar to the increase in SRP concentrations observed at the end of this experiment, could cause systems to shift from transparent to turbid states (Janse et al. 2008). However, this has not been observed in whole lakes that have undergone LMB additions; for instance the LMB-treated shallow Lake Barensee in Germany did not develop any blooms during heatwaves (Epe et al. 2017).

The discrepancy between our lab study and the field observations might be caused by a larger dilution effect in lakes compared to the small water volumes in the cores, by not all binding sites of LMB being rapidly available, by a possible under-dosing in our experimental treatments, or erratic sediment-water transport through ebullitive processes in our cores. The $\mathrm{P}$ inactivation by LMB is a kinetic process, which means that it takes a certain time before all binding sites are occupied (Dithmer et al. 2016), especially in the presence of high DOC (Lurling et al. 2014) as was the case in our system. However, despite the notion that binding sites were potentially not all occupied, LMB was only partially able to counteract the temperature-enhanced $\mathrm{P}$ release in the week after the heatwave exposure, an observation that has been confirmed by an in-situ months-long enclosure experiment (Zhan et al. in prep). Furthermore, we may have potentially under-dosed LMB our experimental treatments, as we did not include the BD-NRP fraction which may also contain organic P (Jan et al. 2015) in our dose estimates. The microbial breakdown of organic matter results in release of organic phosphate to pore waters and can be considered one of the most important source of phosphate (Föllmi 1996). As organic matter breakdown is expected to be enhanced by increased temperature (Gudasz et al. 2010), part of the liberated $\mathrm{P}$ is taken up by the decomposing bacteria, and part will enter the overlying water column. In addition, the ebullition that transports sediment-P might be enhanced under heatwave conditions (Aben et al. 2017). Therefore, inclusion of the BD-NRP and targeting also deeper layers of the sediment in dose estimations are highly recommended for lake managers applying LMB as a eutrophication control measure, especially to counteract the heatwave impacts.

Our results showed that the rates in the $\mathrm{N}$-cycle processes were significantly changed upon exposure to a heatwave, irrespective of treatment. At the start of our experiment, the sediment incubations were anoxic, with $\mathrm{NH}_{4}-\mathrm{N}$ as the dominant nitrogen form accumulating in the overlying water. As dissolved oxygen concentrations rose over time, nitrification became a more dominant process, decreasing ammonium accumulation and leading to increased oxidized nitrogen concentrations (Fig. 3). Rysgaard et al. (1994) demonstrated that nitrification is stimulated by increasing $\mathrm{O}_{2}$ in the $\mathrm{O}_{2}$ range of 0-9.6 $\mathrm{mg} / \mathrm{L}$, which was the case in our experiment. Upon exposure to a heatwave $\left(30{ }^{\circ} \mathrm{C}\right)$, the oxidation of $\mathrm{NH}_{4}-\mathrm{N}$ was accelerated, indicating a positive response of nitrification to increasing temperature. Thamdrup and Fleischer (1998) demonstrated that the optimum temperature for nitrification in warm temperate sediment was near $40{ }^{\circ} \mathrm{C}$. The decline of oxidized nitrogen concentrations $\left(\mathrm{NO}_{3}-\right.$ $\mathrm{N}+\mathrm{NO}_{2}-\mathrm{N}$ ) in the heatwave groups during the postheatwave phase could be associated with the depletion of ammonium. Nitrification can operate at low ammonium concentration but at low rates (Dodds and Jones 1987). Moreover, denitrification is expected to be stimulated with increasing temperature (Veraart et al. 2011). Though we did not measure denitrification directly, denitrification was plausibly leading to an increased consumption of $\mathrm{NO}_{3}-\mathrm{N}$ and $\mathrm{NO}_{2}-\mathrm{N}$, therefore decreasing $\mathrm{N}$-release into the overlying water. The LMB treatment showed no effect on N-dynamics, which supports our conclusion that LMB acted as a chemical binding compound of DRP rather than a physical barrier for nutrient release from the sediments. A recent study by Zeller and Alperin (2021), however, showed that LMB can act as $\mathrm{NH}_{4}-\mathrm{N}$ source with an increase in $\mathrm{NH}_{4}-\mathrm{N}$ concentration by $10-275 \%$. This difference between our results and Zeller and Alperin (2021) might be attributed to the fact that their LMB dose was more than double of ours (0.029 compared to $0.013 \mathrm{~g} \mathrm{LMB} / \mathrm{cm}^{2}$ sediment) and the overlying water volume was much smaller in their experiment (150 $\mathrm{mL}$ compared to $863 \mathrm{~mL})$, resulting in higher LMB concentrations. 
Heatwave effects on greenhouse gas emissions

In our experimental system, regardless of the treatments, concentrations of greenhouse gases (GHG) initially decreased $\left(\mathrm{CO}_{2}\right.$ and $\left.\mathrm{CH}_{4}\right)$, or were close to zero $\left(\mathrm{N}_{2} \mathrm{O}\right)$. Earlier studies on freshwater ecosystems demonstrate increased GHG emissions under warming scenarios (Bartosiewicz et al. 2016; Aben et al. 2017; Bergen et al. 2019). In our experiment, exposure to a heatwave did lead to increased concentrations of $\mathrm{CO}_{2}$ and $\mathrm{N}_{2} \mathrm{O}$. For $\mathrm{CH}_{4}$, however, after an initial short-lived increase during the heatwave itself, the heatwaveexposed treatments had lower $\mathrm{CH}_{4}$ concentrations relative to the non-heatwave exposed group towards the end of the experiments (Fig. 5). A potential explanation for this might be that on the longer term, substrate limitation for methanogens (Duc et al. 2010) may play a stronger role in the heatwave exposed cultures, potentially due to the short-lived increase in methane production during the heatwave. Note that our sediment incubation was conducted under dark condition, different patterns might emerge in real lakes in the presence of primary producers, which points to the importance of validating our results with field observations.

Previous studies on shallow aquatic systems demonstrated that greenhouse gas emissions are higher in eutrophic systems than in more oligotrophic systems (Davidson et al. 2015; Peacock et al. 2019). We therefore hypothesized that LMB treatments, by reducing nutrient availability, would inhibit bacteria growth and subsequently reduce GHG productions. In disagreement with our hypothesis, our results showed that addition of LMB, although effective in blocking sediment P-release, did not affect the GHG emissions from the sediments. Previous studies (Dithmer et al. 2016) demonstrated that LMB needs time (up to months) to bind all available $\mathrm{P}$ in sediments. Another potential cause may be that our doses applied theoretically can only target top $3.3 \mathrm{~cm}$ sediment, which is about $20-25 \%$ of the sediment column, leaving ample space for bacterial activity and methanogenesis in deeper layers. Under warmer conditions the sediment layers available for bacterial activity and methanogenesis may be located deeper, because anoxia is expected to be stronger (Jankowski et al. 2006), associated with enhanced methanogenesis (Schulz et al. 1997). Nonetheless, our results indicate that LMB might not be an effective method in controlling
GHG emissions, at least in the short term. For reduction of carbon associated $\mathrm{GHG}$ emissions $\left(\mathrm{CH}_{4}\right.$ and $\mathrm{CO}_{2}$ ) measures that directly target the reduction of organic matter inputs into sediments, such as an improvement of water treatment in the catchment (Jones et al. 2016) and control of bank soil erosion (Rickson 2014), may be more favourable.

$\mathrm{N}_{2} \mathrm{O}$ is typically derived during nitrification of $\mathrm{NH}_{4}-\mathrm{N}$ under oxic conditions and from the coupled nitrification-denitrification reactions under suboxic conditions, which explains the increase in $\mathrm{N}_{2} \mathrm{O}$ coinciding with the $\mathrm{NH}_{4}-\mathrm{N}$ decrease. Both nitrification and denitrification are strongly temperature-dependent (Veraart et al. 2011; de Klein et al. 2017). Heatwave treatments in our experiment had higher $\mathrm{N}_{2} \mathrm{O}$ concentrations, coinciding with a drop in $\mathrm{O}_{2}$ concentrations, which further indicates that freshwater $\mathrm{N}_{2} \mathrm{O}$ emissions can be strongly temperature dependent and can be boosted under climate change (Parton et al. 2001; Veraart et al. 2011). The decline in $\mathrm{N}_{2} \mathrm{O}$ concentrations in the post-heatwave phase in heatwave-treated groups could be because $\mathrm{NH}_{4}-\mathrm{N}$ for nitrification became limiting, while denitrification in deeper sediment layers increased in efficiency, reducing the $\mathrm{N}_{2} \mathrm{O}: \mathrm{N}_{2}$ ratio in the final product (van de Leemput et al. 2011). Conventional biological denitrification requires low oxygen concentration less than $0.2 \mathrm{mg} / \mathrm{L}$ (Seitzinger et al. 2006). Even when the water column was oxygenated, these concentrations still occurred in anoxic microsites in the sediments of our experimental cores (Fig. S4). In addition, aerobic denitrification has also been observed in freshwater sediments (Trevors and Starodub 1987; Rysgaard et al. 1994; Lv et al. 2017) as well as in coastal sediments (Marchant et al. 2017). Moreover, the pathway of dissimilatory nitrate reduction to ammonium (DNRA) could also contribute to part of the production of $\mathrm{N}_{2} \mathrm{O}$ (Sun et al. 2016). $\mathrm{A}^{15} \mathrm{~N}$ tracing technique (Müller et al. 2014) is needed to determine which pathway is mainly responsible for the production of $\mathrm{N}_{2} \mathrm{O}$.

\section{Conclusions and recommendations}

Our sediment incubation experiment indicates that the rates of biogeochemical processes can be significantly accelerated upon heatwave exposure, resulting in a change in fluxes of nutrient and greenhouse gases between sediment and water column. The current 
efforts in eutrophication control will face more challenges under future climate scenario with more frequent and intense extreme events as predicted by the IPCC.

The effectiveness of widely established eutrophication control measure LMB was, at least temporarily, impaired upon exposure to an extreme heatwave, with an increase in concentration of $0.08 \pm 0.03 \mathrm{mg} \mathrm{P} / \mathrm{L}$ with an overlying water volume of $863 \pm 21 \mathrm{~mL}$, equalling $50 \%$ increase relative to non-heatwave treatments. Although the effect of the heatwave on P-release of LMB treated sediments persisted until the end of the experiment, long term studies should address whether the P-concentrations eventually return to lower pre-heatwave levels. In addition, further research is needed to explore whether increased LMB dosage can mitigate the negative impacts of a heatwave. Nonetheless, our study does suggest that our current abatement efforts may be hampered under climate change, which calls for consideration of more climate-robust measures, such as through revisiting dose-response relationships in the development of rehabilitation plans.

Exposure to a heatwave resulted in higher dissolved GHG concentrations with an increased $\mathrm{CO}_{2}$-equivalent by $106 \%$, showing potential for increased emissions relative to non-heatwave exposed treatments. Our experiment showed that LMB addition did not lead to lower GHG concentrations, which implies that inhibiting microbial GHG production by creating a P-limiting environment through LMB is ineffective. Thus, alternative strategies directly targeting reduction in organic load such as sludge removal or erosion control should be explored to effectively mitigate greenhouse gas emission.

Acknowledgements We thank Wendy Beekman-Lukassen and Nico Helmsing for their assistance. We thank Paul Bodelier for helpful discussions.

Author contributions All authors contributed to the study conception and design. Material preparation, data collection and analysis were performed by all authors. The first draft of the manuscript was written by Qing Zhan and Lisette $\mathrm{N}$ de Senerpont Domis, and all authors commented on previous versions of the manuscript. All authors read and approved the final manuscript.

Funding Q. Zhan and Cleo N. Stratmann were funded by the European Union's Horizon 2020 Research and Innovation Programme under the Marie Skłodowska-Curie grant agreement no. 722518 (MANTEL ITN); Q. Zhan received additional funding from the Royal Dutch Academy of Science (KNAW); Kristof Brenzinger received funding from the German research foundation (DFG) BR 5535/1-1.

Availability of data and material All data and material are also available at Zenodo through the following link https://doi. org/10.5281/zenodo.4268173.

Code availability All codes used in analysing the data are also available at Zenodo through the following link https://doi.org/ 10.5281/zenodo.4268173.

\section{Declarations}

Conflict of interest The authors declare that they have no known competing financial interests or personal relationships that could have appeared to influence the work reported in this paper.

Consent to participate All authors are aware of and accept responsibility for the manuscript.

Consent for publication For possible publication in Biogeochemistry. The manuscript has not been previously published, and it is not under consideration by any other journal.

Ethical approval The authors declare no conflict of interest.

Open Access This article is licensed under a Creative Commons Attribution 4.0 International License, which permits use, sharing, adaptation, distribution and reproduction in any medium or format, as long as you give appropriate credit to the original author(s) and the source, provide a link to the Creative Commons licence, and indicate if changes were made. The images or other third party material in this article are included in the article's Creative Commons licence, unless indicated otherwise in a credit line to the material. If material is not included in the article's Creative Commons licence and your intended use is not permitted by statutory regulation or exceeds the permitted use, you will need to obtain permission directly from the copyright holder. To view a copy of this licence, visit http://creativecommons.org/licenses/by/4.0/.

\section{References}

Aben RC, Barros N, Van Donk E et al (2017) Cross continental increase in methane ebullition under climate change. Nat Commun 8:1-8

Bartosiewicz M, Laurion I, Clayer F, Maranger R (2016) Heatwave effects on oxygen, nutrients, and phytoplankton can alter global warming potential of gases emitted from a small shallow lake. Environ Sci Technol 50:6267-6275. https://doi.org/10.1021/acs.est.5b06312 
Beaulieu JJ, DelSontro T, Downing JA (2019) Eutrophication will increase methane emissions from lakes and impoundments during the 21 st century. Nat Commun 10:1375

van Bergen TJHM, Barros N, Mendonça R et al (2019) Seasonal and diel variation in greenhouse gas emissions from an urban pond and its major drivers. Limnol Oceanogr 64:2129-2139. https://doi.org/10.1002/lno.11173

Beutel MW, Horne AJ (1999) A review of the effects of hypolimnetic oxygenation on lake and reservoir water quality. Lake Reservoir Manage 15:285-297

Beutel MW, Horne AJ, Taylor WD et al (2008) Effects of oxygen and nitrate on nutrient release from profundal sediments of a large, oligo-mesotrophic reservoir, Lake Mathews, California. Lake Reservoir Manage 24:18-29

Cabrerizo MJ, Álvarez-Manzaneda MI, León-Palmero E et al (2020) Warming and CO2 effects under oligotrophication on temperate phytoplankton communities. Water Res 173:115579. https://doi.org/10.1016/j.watres.2020.115579

Carpenter SR (2008) Phosphorus control is critical to mitigating eutrophication. Proc Natl Acad Sci 105:11039-11040

Cavalcante H, Araújo F, Noyma NP, Becker V (2018) Phosphorus fractionation in sediments of tropical semiarid reservoirs. Sci Total Environ 619-620:1022-1029. https:// doi.org/10.1016/j.scitotenv.2017.11.204

Copetti D, Finsterle K, Marziali L et al (2016) Eutrophication management in surface waters using lanthanum modified bentonite: a review. Water Res 97:162-174. https://doi. org/10.1016/j.watres.2015.11.056

Davidson TA, Audet J, Jeppesen E et al (2018) Synergy between nutrients and warming enhances methane ebullition from experimental lakes. Nat Clim Chang 8:156-160. https:// doi.org/10.1038/s41558-017-0063-Z

Davidson TA, Audet J, Svenning J-C et al (2015) Eutrophication effects on greenhouse gas fluxes from shallow-lake mesocosms override those of climate warming. Glob Change Biol 21:4449-4463. https://doi.org/10.1111/gcb. 13062

de Klein JJ, Overbeek CC, Jørgensen CJ, Veraart AJ (2017) Effect of temperature on oxygen profiles and denitrification rates in freshwater sediments. Wetlands 37:975-983

DelSontro T, Beaulieu JJ, Downing JA (2018) Greenhouse gas emissions from lakes and impoundments: upscaling in the face of global change. Limnol Oceanogr Lett 3:64-75

Dithmer L, Nielsen UG, Lundberg D, Reitzel K (2016) Influence of dissolved organic carbon on the efficiency of $\mathrm{P}$ sequestration by a lanthanum modified clay. Water Res 97:39-46

Dodds WK, Jones RD (1987) Potential rates of nitrification and denitrification in an oligotrophic freshwater sediment system. Microb Ecol 14:91-100. https://doi.org/10.1007/ BF02011574

Douglas GB (2002) Remediation material and remediation process for sediments

Duc NT, Crill P, Bastviken D (2010) Implications of temperature and sediment characteristics on methane formation and oxidation in lake sediments. Biogeochemistry 100:185-196

Epe TS, Finsterle K, Yasseri S (2017) Nine years of phosphorus management with lanthanum modified bentonite
(Phoslock) in a eutrophic, shallow swimming lake in Germany. Lake Reserv Manag 33:119-129

Föllmi KB (1996) The phosphorus cycle, phosphogenesis and marine phosphate-rich deposits. Earth Sci Rev 40:55-124

Ghasemi A, Zahediasl S (2012) Normality tests for statistical analysis: a guide for non-statisticians. Int $\mathbf{J}$ Endocrinol Metab 10:486

Grizzetti B, Lanzanova D, Liquete C et al (2016) Assessing water ecosystem services for water resource management. Environ Sci Policy 61:194-203

Grolemond G, Wickman H (2011) Dates and times made easy with lubridate. J Stat Softw 40:1-25

Gudasz C, Bastviken D, Steger K et al (2010) Temperaturecontrolled organic carbon mineralization in lake sediments. Nature 466:478-481. https://doi.org/10.1038/nature09186

Halbedel S (2015) Protocol for CO2 sampling in waters by the use of the headspace equilibration technique, based on the simple gas equation; second update. Protocol Exchange. https://doi.org/10.1038/protex.2015.085

Hosper H, Meijer M-L (1993) Biomanipulation, will it work for your lake? A simple test for the assessment of chances for clear water, following drastic fish-stock reduction in shallow, eutrophic lakes. Ecol Eng 2:63-72

Howarth RW, Marino R (2006) Nitrogen as the limiting nutrient for eutrophication in coastal marine ecosystems: evolving views over three decades. Limnol Oceanogr 51:364-376

Jan J, Borovec J, Kopáček J, Hejzlar J (2015) Assessment of phosphorus associated with $\mathrm{Fe}$ and $\mathrm{Al}$ (hydr) oxides in sediments and soils. J Soils Sediments 15:1620-1629

Jankowski T, Livingstone DM, Bührer H et al (2006) Consequences of the 2003 European heat wave for lake temperature profiles, thermal stability, and hypolimnetic oxygen depletion: Implications for a warmer world. Limnol Oceanogr 51:815-819. https://doi.org/10.4319/lo.2006.51. 2.0815

Janse JH, De Senerpont Domis LN, Scheffer M et al (2008) Critical phosphorus loading of different types of shallow lakes and the consequences for management estimated with the ecosystem model PCLake. Limnologica 38:203-219. https://doi.org/10.1016/j.limno.2008.06.001

Jones TG, Evans CD, Freeman C (2016) The greenhouse gas (GHG) emissions associated with aquatic carbon removal during drinking water treatment. Aquat Sci 78:561-572. https://doi.org/10.1007/s00027-015-0458-8

Kalff J, Knoechel R (1978) Phytoplankton and their dynamics in oligotrophic and eutrophic lakes. Annu Rev Ecol Syst 9:475-495

Kim G, Jeong W, Choi S, Khim J (2007) Sand capping for controlling phosphorus release from lake sediments. Environ Technol 28:381-389. https://doi.org/10.1080/ 09593332808618801

Koschorreck M, Prairie YT, Kim J, Marcé R (2021) CO 2 is not like $\mathrm{CH}$ 4-limits of and corrections to the headspace method to analyse pCO 2 in fresh water. Biogeosciences 18:1619-1627

van de Leemput IA, Veraart AJ, Dakos V et al (2011) Predicting microbial nitrogen pathways from basic principles. Environ Microbiol 13:1477-1487. https://doi.org/10.1111/j. 1462-2920.2011.02450.X

Lin J, Qiu P, Yan X et al (2015) Effectiveness and mode of action of calcium nitrate and Phoslock ${ }^{\circledR}$ in phosphorus 
control in contaminated sediment, a microcosm study. Water Air Soil Pollut 226:330. https://doi.org/10.1007/ s11270-015-2590-4

Lindstrom MJ, Bates DM (1988) Newton-Raphson and EM algorithms for linear mixed-effects models for repeatedmeasures data. J Am Stat Assoc 83:1014-1022

Liu D, Wang P, Wei G et al (2013) Removal of algal blooms from freshwater by the coagulation-magnetic separation method. Environ Sci Pollut Res 20:60-65. https://doi.org/ 10.1007/s11356-012-1052-4

Lurling M, Mackay E, Reitzel K, Spears BM (2016) Editoriala critical perspective on geo-engineering for eutrophication management in lakes. Water Res 97:1-10. https://doi.org/ 10.1016/j.watres.2016.03.035

Lürling M, Mucci M (2020) Mitigating eutrophication nuisance: in-lake measures are becoming inevitable in eutrophic waters in the Netherlands. Hydrobiologia. https://doi.org/ 10.1007/s10750-020-04297-9

Lurling M, Waajen G, van Oosterhout F (2014) Humic substances interfere with phosphate removal by lanthanum modified clay in controlling eutrophication. Water Res 54:78-88. https://doi.org/10.1016/j.watres.2014.01.059

Lv P, Luo J, Zhuang X et al (2017) Diversity of culturable aerobic denitrifying bacteria in the sediment, water and biofilms in Liangshui River of Beijing. China Scientific Reports 7:10032. https://doi.org/10.1038/s41598-01709556-9

Magen C, Lapham LL, Pohlman JW et al (2014) A simple headspace equilibration method for measuring dissolved methane. Limnol Oceanogr Methods 12:637-650. https:// doi.org/10.4319/lom.2014.12.637

Marchant HK, Ahmerkamp S, Lavik G et al (2017) Denitrifying community in coastal sediments performs aerobic and anaerobic respiration simultaneously. ISME J 11:1799-1812

Mucci M, Maliaka V, Noyma NP et al (2018) Assessment of possible solid-phase phosphate sorbents to mitigate eutrophication: Influence of $\mathrm{pH}$ and anoxia. Sci Total Environ 619:1431-1440

Müller C, Laughlin RJ, Spott O, Rütting T (2014) Quantification of $\mathrm{N} 2 \mathrm{O}$ emission pathways via a $15 \mathrm{~N}$ tracing model. Soil Biol Biochem 72:44-54. https://doi.org/10.1016/j.soilbio. 2014.01.013

Oksanen J, Blanchet FG, Friendly M, et al (2019) vegan: Community Ecology Package

Parton WJ, Holland EA, Grosso SJD et al (2001) Generalized model for NO $\mathrm{x}$ and $\mathrm{N} 2 \mathrm{O}$ emissions from soils. J Geophys Res 106:17403-17419. https://doi.org/10.1029/ 2001JD900101

Peacock M, Audet J, Jordan S et al (2019) Greenhouse gas emissions from urban ponds are driven by nutrient status and hydrology. Ecosphere 10:e02643. https://doi.org/10. 1002/ecs 2.2643

Pinheiro J, Bates D, DebRoy S, et al (2019) nlme: linear and nonlinear mixed effects models

Redfield AC (1958) The biological control of chemical factors in the environment. Am Sci 46:230A-A221

Rickson RJ (2014) Can control of soil erosion mitigate water pollution by sediments? Sci Total Environ 468-469:1187-1197. https://doi.org/10.1016/j.scitotenv. 2013.05.057
Rysgaard S, Risgaard-Petersen N, Peter SN et al (1994) Oxygen regulation of nitrification and denitrification in sediments. Limnol Oceanogr 39:1643-1652. https://doi.org/10.4319/ 10.1994.39.7.1643

Schindler DW (1974) Eutrophication and recovery in experimental lakes: implications for lake management. Science 184:897-899

Schulz S, Matsuyama H, Conrad R (1997) Temperature dependence of methane production from different precursors in a profundal sediment (lake constance). FEMS Microbiol Ecol 22:207-213. https://doi.org/10.1111/j. 1574-6941.1997.tb00372.x

Seitzinger S, Harrison JA, Böhlke JK et al (2006) Denitrification across landscapes and waterscapes: a synthesis. Ecol Appl 16:2064-2090

Smith VH, Joye SB, Howarth RW (2006) Eutrophication of freshwater and marine ecosystems. Limnol Oceanogr 51:351-355

Smith VH, Tilman GD, Nekola JC (1999) Eutrophication: impacts of excess nutrient inputs on freshwater, marine, and terrestrial ecosystems. Environ Pollut 100:179-196

Søndergaard M, Bjerring R, Jeppesen E (2013) Persistent internal phosphorus loading during summer in shallow eutrophic lakes. Hydrobiologia 710:95-107

Sun Y, De Vos P, Heylen K (2016) Nitrous oxide emission by the non-denitrifying, nitrate ammonifier Bacillus licheniformis. BMC Genomics 17:68. https://doi.org/10.1186/ s12864-016-2382-2

Team RC (2019) R: a language and environment for statistical computing. Team RC, Vienna

Thamdrup B, Fleischer S (1998) Temperature dependence of oxygen respiration, nitrogen mineralization, and nitrification in Arctic sediments. Aquat Microb Ecol 15:191-199. https://doi.org/10.3354/ame015191

Trevors JT, Starodub ME (1987) Effect of oxygen concentration on denitrification in freshwater sediment. J Basic Microbiol 27:387-391. https://doi.org/10.1002/jobm.3620270711

Veraart AJ, de Klein JJM, Scheffer M (2011) Warming can boost denitrification disproportionately due to altered oxygen dynamics. PLoS ONE 6:e18508. https://doi.org/10. 1371/journal.pone.0018508

Verpoorter C, Kutser T, Seekell DA, Tranvik LJ (2014) A global inventory of lakes based on high-resolution satellite imagery. Geophys Res Lett 41:6396-6402. https://doi.org/10. 1002/2014GL060641

Villanueva RAM, Chen ZJ (2019) ggplot2: elegant graphics for data analysis, 2nd edition. Meas-Interdiscip Res Perspect 17:160-167. https://doi.org/10.1080/15366367.2019. 1565254

Visser PM, Ibelings BW, Bormans M, Huisman J (2016) Artificial mixing to control cyanobacterial blooms: a review. Aquat Ecol 50:423-441. https://doi.org/10.1007/s10452015-9537-0

Waldman DM (1983) A note on algebraic equivalence of White's test and a variation of the Godfrey/Breusch-Pagan test for heteroscedasticity. Econ Lett 13:197-200

Weiss RF (1974) Carbon dioxide in water and seawater: the solubility of a non-ideal gas. Mar Chem 2:203-215. https:// doi.org/10.1016/0304-4203(74)90015-2

Weiss RF, Price BA (1980) Nitrous oxide solubility in water and seawater. Mar Chem 8:347-359 
Woolway RI, Jennings E, Shatwell T et al (2021) Lake heatwaves under climate change. Nature 589:402-407. https:// doi.org/10.1038/s41586-020-03119-1

Yamamoto S, Alcauskas JB, Crozier TE (1976) Solubility of methane in distilled water and seawater. J Chem Eng Data 21:78-80

Zamparas M, Gianni A, Stathi P et al (2012) Removal of phosphate from natural waters using innovative modified bentonites. Appl Clay Sci 62-63:101-106. https://doi.org/ 10.1016/j.clay.2012.04.020

Zeller MA, Alperin MJ (2021) The efficacy of Phoslock ${ }^{\circledR}$ in reducing internal phosphate loading varies with bottom water oxygenation. Water Res X 11:100095. https://doi. org/10.1016/j.wroa.2021.100095

Zhan Q, Teurlincx S, Raman N, et al Towards climate-robust water quality management: testing the efficacy of different eutrophication control measures during a heatwave in an urban canal

Zhang S, Zhou Q, Xu D et al (2010) Effects of sediment dredging on water quality and zooplankton community structure in a shallow of eutrophic lake. J Environ Sci 22:218-224. https://doi.org/10.1016/S1001-0742(09)009 6-6

Zuur A, Ieno EN, Walker N et al (2009) Mixed effects models and extensions in ecology with R. Springer Science \& Business Media, New York

Publisher's Note Springer Nature remains neutral with regard to jurisdictional claims in published maps and institutional affiliations. 